\title{
African Mask-Making Workshop: Professional Development Experiences of Diverse Participants
}

\author{
Audrey C. Rule \\ University of Northern lowa \\ U.S.A. \\ Sarah E. Montgomery \\ University of Northern lowa \\ U.S.A. \\ Gloria Kirkland-Holmes \\ University of Northern lowa \\ U.S.A. \\ Dwight C. Watson \\ University of Northern lowa \\ U.S.A. \\ Yvonne Ayesiga \\ Wartburg College \\ U.S.A.
}

ABSRACT: Diverse education professionals learned about African cultures in a workshop experience by making African masks using authentic symbolism. Analysis of reflections to evaluate the workshop for applicability to participants with and without African heritage showed that both groups expanded their cultural knowledge of traditional African ethnic groups. Those participants with African heritage noted valuing of women while those without African heritage expressed appreciation for African culture, self-evaluation of work, and the desire to investigate their own heritages.

KEYWORDS: multicultural art, African mask-making, professional development, multicultural workshop, teacher education

\section{Cultural Competency}

How the Arts Support Cultural Competency

The African Mask-making Workshop

Workshop Evaluation Results and Discussion

Conclusion

References

Author Contact 
Africa, the world's second largest continent, has 54 nations, each with multiple ethnicities. The diversity on the continent is exemplified through people's customs, rituals, and symbols, which are direct representations of cultural heritage. The use of traditional masks in ceremonies indicates the importance of these artifacts in African culture. Most African masks represent spirits of ancestors, royalty, accomplished hunters or warriors, animals, natural features such as mountains or lakes, or supernatural beings (Hahner, Kecskesi, \& Vajda, 2007). Masks are generally not worn alone but with a body-covering made of raffia, leaves, or cloth. As the costumed dancers move to the rhythm of instruments and voices, the masquerader is transformed into the spirit being portrayed (Bassani, 2005). These ceremonies transmit the cultural heritage of the group to future generations.

A central object of many ceremonies is the mask covering the performer's face that forms a connection to the supernatural. This artifact is often beautifully crafted and rich in symbolism, but it is not for Art per se. The maker of the work, through intentional activity, makes the work an artwork or not. "The response of others to the work...cannot make something be an artwork that was not conceived and projected in a certain way by its creator" (Galbusera \& Levinson, 2012, p. 81). Therefore, masks made primarily for religious or social purposes should not be considered Art in the contemporary meaning of the word; rather they should instead be thought of as artifacts or cultural arts, meaning skilled works that incorporate cultural beliefs, values, aesthetics, and symbolism. In contrast, masks made by workshop participants to be displayed at home as decorative objects that represent chosen symbols, favorite colors, and other personally meaningful traits may be considered artworks through the intentions of the makers. Table 1 provides information on the masks of the six African groups on which this article focuses. These masks have unique symbolic characteristics that tie closely to the mask's role in the religious and social structure of the ethnic group. Masks were used to connect members of the community with deceased ancestors or other spirits for human benefit.

This article uses African masks to spark appreciation for these cultural arts, supporting positive racial identities for African American students through appreciation of their rich heritage and improving teachers' cultural competency through increased knowledge of the distinct mask-making and mask-using traditions of different African ethnic groups. Jackson (2012), in discussing new perspectives in his Black Identity Development (BID) Theory, notes that knowledge of Black history, heritage, and cultural contributions impacts racial identity:

Depending on the salience of Black culture in their growing up experience, the Black cultural messages do have an effect on the BID process. The philosophical and theological messages and experiences, the exposure to the shared historical experiences and contributions to the Black community and the larger society made by other Black people, the implicit and explicit lessons taught about the nature and structure of the Black 
family and other intra-group interactions, are significant to the BID process. (p. 41)

Boyd-Franklin (2013), a clinical psychologist, discussed African Americans as being a tremendously diverse cultural group that shares three main areas of experience: African legacy, history of slavery, and racial discrimination. She recognized how African culture still affects the psychology of African Americans:

The other aspect of the African legacy that must be recognized by clinicians who work with African American families is the central role of religion and spiritual beliefs in many Black families. These beliefs, while permeating every aspect of the African's life, served the further purpose of the tribe. (p. 6)

Table 1

Mask Information for Six African Cultural Groups

\begin{tabular}{|c|c|c|c|c|c|c|}
\hline $\begin{array}{l}\text { Cultural } \\
\text { Group }\end{array}$ & Yoruba & Bembe & Massai & Bamana & Chokwe & Luba \\
\hline $\begin{array}{l}\text { Homeland } \\
\text { Area }\end{array}$ & Nigeria, Benin & $\begin{array}{l}\text { Democratic } \\
\text { Republic of } \\
\text { Congo, } \\
\text { Tanzania }\end{array}$ & $\begin{array}{l}\text { Kenya, } \\
\text { Tanzania }\end{array}$ & Mali & $\begin{array}{l}\text { Angola, } \\
\text { Zambia, } \\
\text { Democratic } \\
\text { Republic of } \\
\text { Congo }\end{array}$ & $\begin{array}{l}\text { Democratic } \\
\text { Republic of } \\
\text { Congo }\end{array}$ \\
\hline $\begin{array}{l}\text { Mask } \\
\text { Style }\end{array}$ & $\begin{array}{l}\text { Helmet crest } \\
\text { mask covering } \\
\text { head top and } \\
\text { forehead; veil } \\
\text { hiding face }\end{array}$ & $\begin{array}{l}\text { Shield-shaped } \\
\text { or round face } \\
\text { mask }\end{array}$ & $\begin{array}{l}\text { Face mask } \\
\text { with } \\
\text { headdress }\end{array}$ & $\begin{array}{l}\text { Helmet crest } \\
\text { mask with veil } \\
\text { or face mask }\end{array}$ & $\begin{array}{l}\text { Face mask } \\
\text { with added wig }\end{array}$ & $\begin{array}{l}\text { Many styles, } \\
\text { circular face } \\
\text { masks }\end{array}$ \\
\hline Materials & $\begin{array}{l}\text { Painted carved } \\
\text { wood }\end{array}$ & $\begin{array}{l}\text { Painted } \\
\text { carved wood, } \\
\text { raffia }\end{array}$ & $\begin{array}{l}\text { Red-painted, } \\
\text { carved wood }\end{array}$ & $\begin{array}{l}\text { Carved wood, } \\
\text { cowry shells, } \\
\text { brass }\end{array}$ & $\begin{array}{l}\text { Carved wood, } \\
\text { plant fibers for } \\
\text { hair; }\end{array}$ & $\begin{array}{l}\text { Carved wood, } \\
\text { beads, metals }\end{array}$ \\
\hline $\begin{array}{l}\text { Mask } \\
\text { Traits }\end{array}$ & $\begin{array}{l}\text { Cheek } \\
\text { scarification lines } \\
\text { show clan } \\
\text { identification (Ola } \\
\text { Orie, 2011); bright } \\
\text { colors and } \\
\text { expressions } \\
\text { indicate joviality of } \\
\text { Gelede festival }\end{array}$ & $\begin{array}{l}\text { Shield masks } \\
\text { have pairs of } \\
\text { partly-closed } \\
\text { eyes; animal } \\
\text { masks have } \\
\text { pointy chins, } \\
\text { beaks, horns, } \\
\text { and manes } \\
\text { (Hamill } \\
\text { Gallery of } \\
\text { Tribal Art, } \\
\text { 2010) }\end{array}$ & $\begin{array}{l}\text { Traditional } \\
\text { warrior } \\
\text { hairstyle of red } \\
\text { braids; animal } \\
\text { images and } \\
\text { patterns }\end{array}$ & $\begin{array}{l}\text { Ntomo society } \\
\text { masks have } \\
\text { row of horns; } \\
\text { Tyi Wara } \\
\text { helmet crest } \\
\text { masks feature } \\
\text { antelopes }\end{array}$ & $\begin{array}{l}\text { Pwo masks } \\
\text { depict ideal } \\
\text { women with } \\
\text { symmetrical } \\
\text { faces, } \\
\text { scarification } \\
\text { designs, and } \\
\text { braided } \\
\text { hairstyles } \\
\text { (Finley, 1999) }\end{array}$ & $\begin{array}{l}\text { One type is a } \\
\text { circular with } \\
\text { large round } \\
\text { eyes. Often } \\
\text { triangular } \\
\text { metallic pieces } \\
\text { encircle the } \\
\text { mask. }\end{array}$ \\
\hline $\begin{array}{l}\text { Example } \\
\text { Cultural } \\
\text { Mask } \\
\text { Event }\end{array}$ & $\begin{array}{l}\text { Gelede festival } \\
\text { honors women, } \\
\text { especially } \\
\text { powerful Great } \\
\text { Mothers, elder } \\
\text { women or female } \\
\text { ancestors } \\
\text { (Brooklyn } \\
\text { Museum, 2007), } \\
\text { who have } \\
\text { supernatural } \\
\text { powers } \\
\text { (Makinde,2004). }\end{array}$ & $\begin{array}{l}\text { Elanda male } \\
\text { society } \\
\text { dances } \\
\text { feature masks } \\
\text { of ancestors } \\
\text { who intervene } \\
\text { for a } \\
\text { successful } \\
\text { hunt; other } \\
\text { masks often } \\
\text { represent } \\
\text { forest spirits. }\end{array}$ & $\begin{array}{l}\text { Warrior and } \\
\text { hunting masks } \\
\text { ensure } \\
\text { success. } \\
\text { Masks are } \\
\text { made for } \\
\text { tourists. New } \\
\text { mask motifs } \\
\text { appear in } \\
\text { dreams and } \\
\text { are approved } \\
\text { by the elders. }\end{array}$ & $\begin{array}{l}\text { Ntomo society } \\
\text { masks are } \\
\text { used in } \\
\text { manhood } \\
\text { initiation. Tyi } \\
\text { Wara is the } \\
\text { legendary } \\
\text { antelope who } \\
\text { brought } \\
\text { agriculture } \\
\text { and who visits } \\
\text { the fields } \\
\text { during } \\
\text { planting. }\end{array}$ & $\begin{array}{l}\text { Male initiation } \\
\text { rites have } \\
\text { masked } \\
\text { performers } \\
\text { teaching } \\
\text { initiates. } \\
\text { Mwana Pwo } \\
\text { dancers wear } \\
\text { fitted net } \\
\text { costumes, and } \\
\text { move } \\
\text { gracefully, } \\
\text { displaying } \\
\text { good manners. }\end{array}$ & $\begin{array}{l}\text { Shrines have } \\
\text { ceremonies } \\
\text { with masked } \\
\text { performers for } \\
\text { the living to } \\
\text { remember and } \\
\text { speak to the } \\
\text { dead obtaining } \\
\text { important } \\
\text { information } \\
\text { (Vecsey, } \\
\text { 1983). }\end{array}$ \\
\hline
\end{tabular}




\begin{tabular}{|c|c|c|c|c|c|c|}
\hline $\begin{array}{l}\text { Mask } \\
\text { Symbols }\end{array}$ & $\begin{array}{l}\text { Birds represent } \\
\text { spiritual powers, } \\
\text { as some women } \\
\text { can turn into birds } \\
\text { and visit others at } \\
\text { night; snakes } \\
\text { symbolize life } \\
\text { force (Hommel, } \\
2011) \text {; and } \\
\text { crowns represent } \\
\text { royalty. }\end{array}$ & $\begin{array}{l}\text { Rows of partly } \\
\text { closed eyes } \\
\text { represent } \\
\text { watchful eyes } \\
\text { of ancestors. }\end{array}$ & $\begin{array}{l}\text { Elaborate } \\
\text { carving of } \\
\text { designs and } \\
\text { patterns } \\
\text { represents the } \\
\text { personality of } \\
\text { the maker } \\
\text { rather than } \\
\text { scarification } \\
\text { patterns used } \\
\text { by the Maasai } \\
\text { (Jamison, } \\
\text { 1999). }\end{array}$ & $\begin{array}{l}\text { Even number } \\
\text { of horns } \\
\text { indicates a } \\
\text { female } \\
\text { guiding spirit. } \\
\text { Small mouths } \\
\text { and large ears } \\
\text { mean listen in } \\
\text { silence } \\
\text { (Colleyn \& } \\
\text { Farrell, 2001). } \\
\text { Large nose } \\
\text { indicates } \\
\text { great empathy } \\
\text { as the nose is } \\
\text { considered } \\
\text { the center of } \\
\text { emotion. } \\
\text { Cowry shells } \\
\text { symbolize } \\
\text { femininity or } \\
\text { wealth. }\end{array}$ & $\begin{array}{l}\text { Mwana Pwo } \\
\text { embodies the } \\
\text { ideal woman } \\
\text { through a } \\
\text { female } \\
\text { ancestor, } \\
\text { sometimes a } \\
\text { chief or chief's } \\
\text { wife, signified } \\
\text { by a diadem } \\
\text { (Jordán et al., } \\
\text { 2000). }\end{array}$ & $\begin{array}{l}\text { A person's life- } \\
\text { force becomes } \\
\text { stronger with } \\
\text { age. After } \\
\text { death, spirits' } \\
\text { life forces } \\
\text { disappear } \\
\text { unless living } \\
\text { persons } \\
\text { strengthen } \\
\text { them by using } \\
\text { their names. } \\
\text { The all-seeing } \\
\text { spirits speak } \\
\text { through masks } \\
\text { to help the } \\
\text { living. Crests } \\
\text { on such } \\
\text { masks indicate } \\
\text { male spirits. }\end{array}$ \\
\hline
\end{tabular}

The purpose of focusing on masks in the workshop described by this article was to give the participants a perspective of how masks are an integral part of sophisticated cultures with coherent religious and social beliefs, contrary to the stereotype promoted by European colonial powers of traditional African ethnic groups being "primitive" or "savage" (Herskovits, 2004). These stereotypes continue today; for example, German geography and history textbooks describe Africa as "exotic," "strange," and a "dark undiscovered continent" (Marmer, Marmer, Hitomi, \& Sow, 2011, p. 4-5), leading students to perceive those of African descent as "lazy" or "wild" (p. 1). A professor of African studies found that college students often maintain stereotyped images of indigenous African cultures: "native, hut, warrior, shield, tribe, savage, cannibals, jungle, Pygmy, pagan, voodoo, and witch doctor" (Keim, 2009, p. 4). Keim (2009) also recounts some widely held misconceptions about Africa: "Africa is just one large country; Africa is all jungle; Africans share a single culture, language, and religion; Africans live in 'grass huts'; Africans mainly hunt animals for their subsistence; and Africa has no significant history" (p. 5). Many of these misconceptions originate deep in American history and were proliferated by those in power to maintain a view of Africans as inferiors for their exploitation. "Accurate information about ethnic and cultural diversity [is] necessary for both minority and majority students to counteract the negative discriminations and distortions perpetuated in conventional conceptions of knowledge and truth, in schooling generally, and in society at large" (Gay, 2015, p. 49).

In this article, the authors, two African-American professors, two White professors, and an African graduate student, report the results of an African mask-making experience for education professionals self-identified as being with or without African heritage to determine the usefulness of mask-making in cultural education to both groups of participants. 


\section{Cultural Competency}

The U.S. society and the population of school-age students are becoming increasingly diverse (National Center for Educational Statistics, 2014), which requires schools to make adjustments to serve all students well. This process involves building trust, engaging personal culture, confronting social justice issues, changing instructional practices, and engaging the entire school community (Howard, 2007). A challenge to teachers of addressing the diverse cultures present in schools is the fact that most public school teachers are White, grew up in middle-class households, and received their teacher preparation in predominantly White colleges (Gay, Dingus, \& Jackson, 2003). Many teachers lack necessary background to understand the diverse cultures of students; this deficit may be addressed through appropriate professional development in multiculturalism. This article describes a successful workshop that focused on learning about the connections of different masks to religious and social aspects of six African cultural groups chosen for their diversity of beliefs and their variety of locations in different countries of Africa. Increasing knowledge of the heritage of African Americans allows teachers and their students to appreciate their cultural roots and assists them in dispelling stereotypes.

In the professional literature, the term "culturally competent" refers to pedagogy that is culturally appropriate, culturally congruent, culturally relevant, and emancipatory (Gay, 2005; Sleeter 2001). Characteristics associated with culturally competent pedagogy include positive perspectives on families; communication of high expectations; learning within the context of culture; student-centered instruction; reshaping the curriculum; and teachers as facilitators (Ladson-Billings, 2005). Culturally competent teachers provide instruction that integrates a wide variety of instructional strategies connected to different approaches to learning (Council of Chief State School Officers, 2013), such as the arts. Professional development opportunities must occur often for these practices to be embedded in the schools' culture, climate, and classrooms (Ladson-Billings, 2005). Culturally responsive teaching goes a step beyond cultural competency. Culturally responsive teaching recognizes the importance of racial and cultural diversity in learning, valuing these differences as assets and using knowledge of diverse heritages, family structures, and communities to guide curriculum and instructional development while challenging racial stereotypes, mediating power imbalances, and accepting this approach as necessary to the educational efficacy for all students (Gay, 2010). In culturally responsive teaching, students not only experience academic success and connect with their cultural heritage, they learn how to recognize, challenge, and transform inequities, injustices, and oppressions (Ladson-Billings, 1995).

The Purnell Model for Cultural Competence was developed to address the increasing multicultural and multilingual nature of healthcare teams and patients (Purnell \& Pontious, 2014). The model includes guidelines for working with 
individuals, families, and communities on the continuum of individualism to collectivism stances so that medical actions, communications, and decisions can be well-understood and applied correctly. The Purnell Model (Purnell, 2002) is based on assumptions such as the following: "Each individual has the right to be respected for his or her uniqueness and cultural heritage," and "Prejudices and biases can be minimized with cultural understanding" (p. 193). Although the Purnell Model was originally developed to assist healthcare workers in becoming culturally competent, this model is applicable to and has been used with educators. The model includes such areas as heritage, family roles and organization, spirituality, and death rituals; these are areas addressed in the mask-making workshop through presentation of mask-related cultural practices of six African cultures.

For example, according to Olajubu (2003), the Yoruba worldview is rooted in holistic harmony between the invisible spiritual world and the visible physical world, with people finding interconnections of these areas in their religious and social realities. The Yoruba recognize a genderless Supreme Being and a host of male and female divinities who depend upon their relevance to the needs of worshippers for their survival. Components of Yoruba religion include belief in spirits, ancestors, supernatural powers, sacrifices, offerings, prayers, songs, and invocations. "The traditional Yoruba way encompasses respect for the elder, nurture and care of the young to become responsible adults, care of the elderly while still alive, and rituals of annual remembrance to keep the memory of the dead alive among the living" (Babatunde \& Setiloane, 2014, p. 242). Yoruba households are patrilineal and often polygamous with men being more privileged than women (Babatunde \& Setiloane, 2014). The role of women in traditional Yoruba society is complex, with wives being able to accumulate property to which their husbands have no claim; however, women generally do not have inheritance rights to their husbands' property (Aluko, 2015). During the Gelede festival, men masquerade as mothers to honor their life-giving fertility and ability to bring stability to society (Casimir, Nwakego, \& Umezinwa, 2015). The great mothers, elderly women or female ancestors, are particularly revered during this festival, as they are believed to possess supernatural powers (Makinde, 2004). Gelede features humorous masks painted bright colors to convey the celebrative spirit of the festival. Applying the Purnell Model (Purnell, 2002), a teacher's understanding of a student's belief in the supernatural or need to honor the wishes of an elder grandmother will assist in negotiating solutions to education issues.

In addition to cultural competence in the local setting, increasing globalization necessitates intercultural competence across nations. Intercultural competency can be divided into content competencies and process-oriented competencies. Content competencies involve general awareness and knowledge of aspects of both the "other" culture and one's own "home" culture. These facets include knowledge of customs, symbols, traditions, rituals, sex roles, history, and language; they may be reductions or stereotypes with accompanying positive or negative values and emotional tones (Allport, 1979). Being content-competent does not ensure full intercultural competency; one must 
go beyond content to successful interaction (Stier, 2006). Such interaction involves alternating between the perspective of an insider and an outsider through self-reflection and role-playing and requires noticing cultural differences without automatically assigning a value judgment (Stier, 2006). Emotional skills of understanding the origins of other people's feelings and effectively coping with one's own feelings of uneasiness in an unfamiliar cultural setting are needed (Gudykunst \& Kim, 2003). Interpersonal competencies of noticing and responding to subtle non-verbal cues and language are also required, along with metacognition of one's interaction style and the ability to react well to context and situation (Stier, 2006).

The mask-making activity was designed to use the arts-based experiences to enhance the cultural competency of participants by appreciation of family roles in several traditional African cultural groups (Ladson-Billings, 2005); recognition of cultural universals (Brophy \& Alleman, 2006) such as communication through spirituality, rituals, symbolism, and rites of passage involving masks; and promoting respect for personal uniqueness through participant choice of design elements of the mask (Purnell, 2002). This approach led participants to non-superficial understandings of how the masks represent and connect to many facets of the six traditional African cultures explored in this workshop. Discussions between participants with and without African heritage facilitated taking new perspectives along with understanding of the feelings of others and how they arose. The mask-making workshop offered the opportunity for participants not only to become more competent regarding cultural content, but also to practice withholding judgment while learning about or experiencing the unfamiliar.

\section{How the Arts Support Cultural Competency}

"The arts can...open pathways toward understanding the richness of peoples and cultures that inhabit our world, particularly during this period of global change" (Bucheli, Goldberg, \& Phillips, 1991). The arts provide an avenue for educators to develop a culturally-responsive curriculum as students learn both about themselves and others (Johnson, 2002). Arts-based experiences prompt empathy, encouraging students to recognize and feel the experiences of others, but also to better understand themselves (Zwirn \& Graham, 2005).

Experiences of studying cultural artifacts and making art can support selfexploration while honoring difference and promoting cultural competency. For example, in a study of high school students who photographed and interviewed immigrants for a cultural journalism project, Graham (2009) found that students developed a critical awareness of race, reported intense enjoyment of the artbased opportunity, and shared an emotional connection to those they interviewed. Students subsequently delved into their own stories, learned more about their own families' experiences, and recognized the trials and triumphs present in a common humanity. Pursuing photography projects in which 
students share their perspectives and hopes through writing about and displaying their photos in a public forum can provide a way to use the arts to expand one's own understandings and that of others about diversity (Graziano, 2011; Montgomery et al., 2014; Zenkov et al., 2013). In a study involving participatory action research, youth from diverse backgrounds took photos of their beliefs of, supports for, and impediments to school. The researchers found that the youth used this arts-based learning opportunity to share their own cultural backgrounds and to inform educators about the need for such culturally relevant pedagogical opportunities in their schools (Zenkov et al., 2013).

While the arts can provide a platform for a culturally responsive curriculum, educators must be careful not to trivialize arts integration into the curriculum through simplistic activities that are considered extras or time-fillers like coloring a picture when a student finishes early. The arts must also combat, instead of reinforce, stereotypes (Waddington, 2012). Arts projects, such as the papier-mâché African mask-making project, should incorporate and extend student understanding of curriculum content, in this case, different social and religious conventions of traditional African cultures (Collins, \& Chandler, 1993; Gullatt, 2008). A study of 65 preservice teachers learning about diversity in Africa found that meaningful intercultural learning took place through an artsintegrated project (Rule \& Montgomery, 2011; Rule et al., 2012). In this investigation, preservice teachers made papier-mâché masks of six cultural groups from Africa and then helped elementary students complete a similar project. After completing the project, 22 of the 65 preservice teachers identified a direct benefit of arts-based education to be deeper learning and retention of cultural content, something no participant believed would occur prior to the project. In fact, many preservice teachers noted their surprise that first and second-grade students understood and remembered the content regarding traditions, beliefs, and values of the six different cultural groups. The impact of the rich cultural learning experience resulted in 48 out of 65 of the preservice teachers reporting that they will possibly teach an arts-integrated project like this in their future classrooms because of the richer and more meaningful learning both groups experienced (Montgomery \& Rule, 2011; Rule \& Montgomery, 2011; Rule et al., 2012).

Although the arts can promote increased cultural competency and educators recognize the positive value of the arts for students (Johnson, 2002), art preparation experiences among educators are lacking (Zwirn \& Graham, 2004). In a study of over 400 educators (Oreck, 2004), one of the most frequently shared responses regarding barriers to using the arts was the educator's need to develop self-efficacy in this area. This suggests the importance of increased art-based professional development for educators, particularly art experiences that embrace difference and promote cultural competency. The current study provides a small facet of this needed professional development by introducing professionals who work with diverse youth to information about several African cultural groups and their mask-making enterprises and by giving them the opportunity to explore these issues through making a personal papier-mâché mask in the style of one of these cultures. As 
in the Reggio approach, the workshop presenters did not provide a pre-designed art project to the participants (Saab \& Stack, 2013). Instead, the workshop organizers provided information about six rich traditional ethnic cultures of Africa with the uses and symbolism of their masks. Then the workshop participants were able to express their individual understandings by combining symbolism and personal connections with the information in making an art product.

\section{The African Mask-Making Workshop}

\section{Participants}

Several settings were used to recruit study participants. The first setting was a two-hour workshop at a professional conference on African American families. Because of severe weather conditions during the conference, an identical second workshop was conducted later for those who wanted to but were prevented from attending the first. A mask workshop was also presented in a graduate education course. All settings hosted a mix of participants with and without African heritage.

The 20 participants were adults aged 18 to 65 years. Ten participants had African heritage (1 African, 9 African American; 8 female, 2 male) while 10 additional participants did not have African heritage (8 Euro-American, 2 MiddleEastern; 6 female, 4 male). Both groups of participants had a similar distribution of ages. This study was approved by the overseeing university's Human Subjects Committee with all workshop participants providing written consent for their comments, poems, responses, and images of masks to be used. All human subject protections were implemented during the project.

\section{Procedure}

The workshop began with a slide show of photographs of authentic masks of six African cultures accompanied by discussion of mask usage and symbolism. A second presenter and co-author who was born and raised in Uganda, a member of the Banyoro tribe, discussed mask usage in several African cultural groups, noting how masks were considered precious, given to children at birth and passed through generations with each owner attaching special charms or commemorative items to the mask. She explained the value attributed to masks by telling that a person whose home was on fire would rescue a valued mask first.

The basic papier-mâché mask forms were prepared by the first author. All mask bases were made by gluing recycled paper on a balloon with craft glue. Large features such as horns or headdresses were added with cardboard. Attendees were asked to create a personally meaningful mask that incorporated symbolism and design features from one or more of the highlighted African cultures. They chose the mask base that best matched their vision of a 
completed mask. Participants received instruction on molding features such as noses or eyes and painted the masks with acrylic paints.

Participants were seated in small groups and encouraged to talk to fellow attendees about their design choices and technical issues of producing a mask. The instructors assisted participants as requested. To foster greater intercultural understanding and appreciation for the uniqueness of personal connections made to the masks, during the last part of the workshop, participants shared their mask work with others, noted the symbolism they had employed, and discussed what they had learned from the presentations and activities. Many participants' completed masks were displayed in the university's library, sparking additional discussion between participants and interested students or faculty.

After completing their masks, participants responded to a set of reflection questions that mirrored the main research objectives of the study to produce the study's data set.

1. What general insights do you have about this project?

2. What adjectives describe your feelings connected to the cultural aspects of this mask?

3. What new intercultural understandings do you have as a result of this workshop?

4. What insights do you have concerning your own cultural identity as a result of working on the mask?

5. Compose a double Cinquain poem about your mask.

\section{Data Analysis for Evaluation of the Workshop}

Participant responses to the questions were placed on a spreadsheet for sorting. The data consisted of all written responses to the five questions listed in the previous section from the 20 participants. The constant comparison method was used in which similar responses to each of the questions were grouped into categories while simultaneously comparing all the responses to the given question. The categories were repeatedly refined as new responses were read, changing the category labels to define new relationships (Dye, Schatz, Rosenberg, \& Coleman, 2000). Category headings shown on the tables fell into two types: (a) representative quotes taken from participant responses with other very similar statements being grouped with this quote; and (b) a general theme with quoted example words that had been classified as fitting the theme. The responses of the two groups, those with and those without African heritage, were compared to determine similarities and differences in reactions to the maskmaking workshop. 


\section{Workshop Evaluation Results and Discussion}
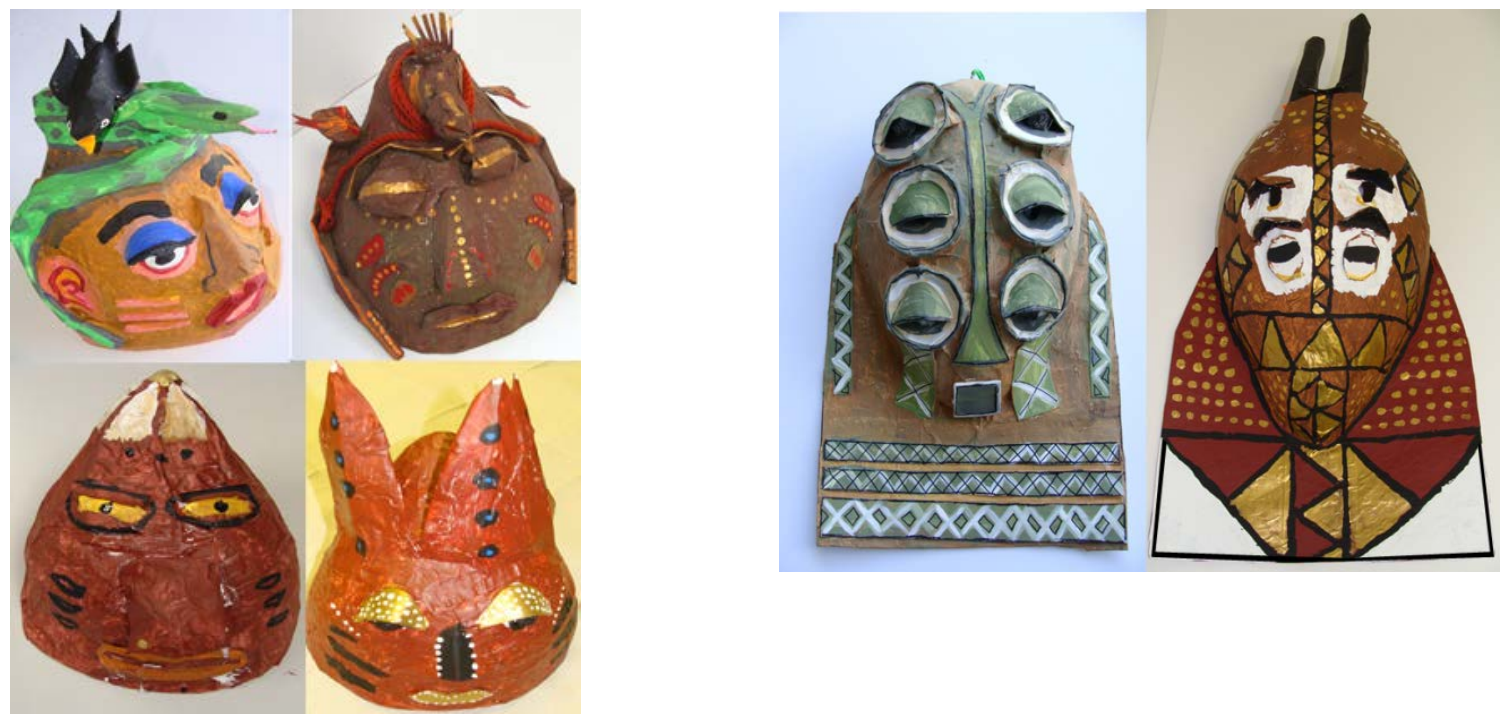

Figure 1. Yoruba-style masks (four at left) \& Bembe Shield-style masks (two at right)
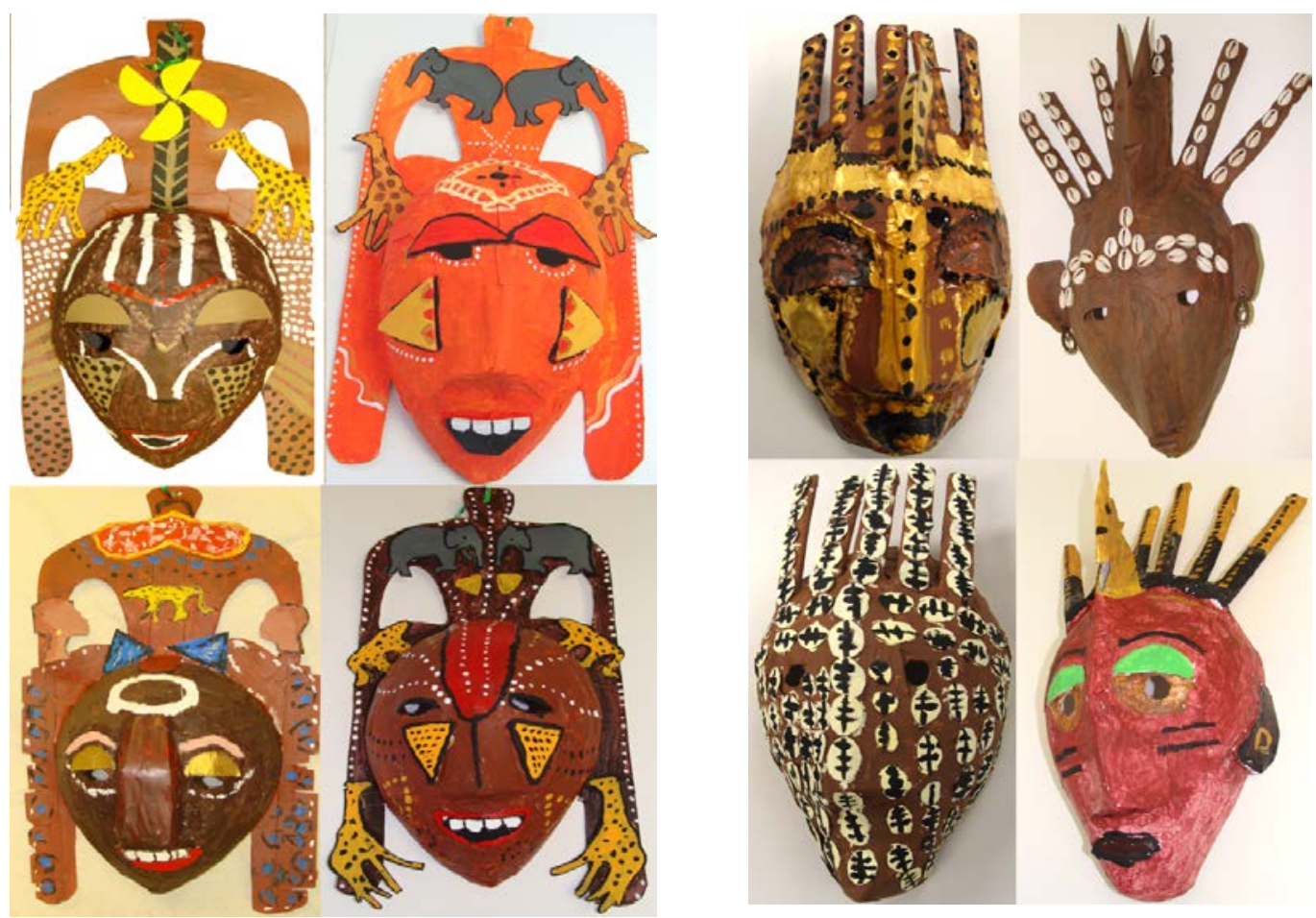

Figure 2. Maasai-style masks (four at left) \& Bamana-style masks (four at right) 
In most aspects of this project, both groups of participants reacted similarly, enjoying the mask making, recognizing their creativity, and finding the activities meaningful. Figures 1 through 3 show images of masks made by participants. In general, once mask-making was underway, participants became entirely absorbed in their creative work.
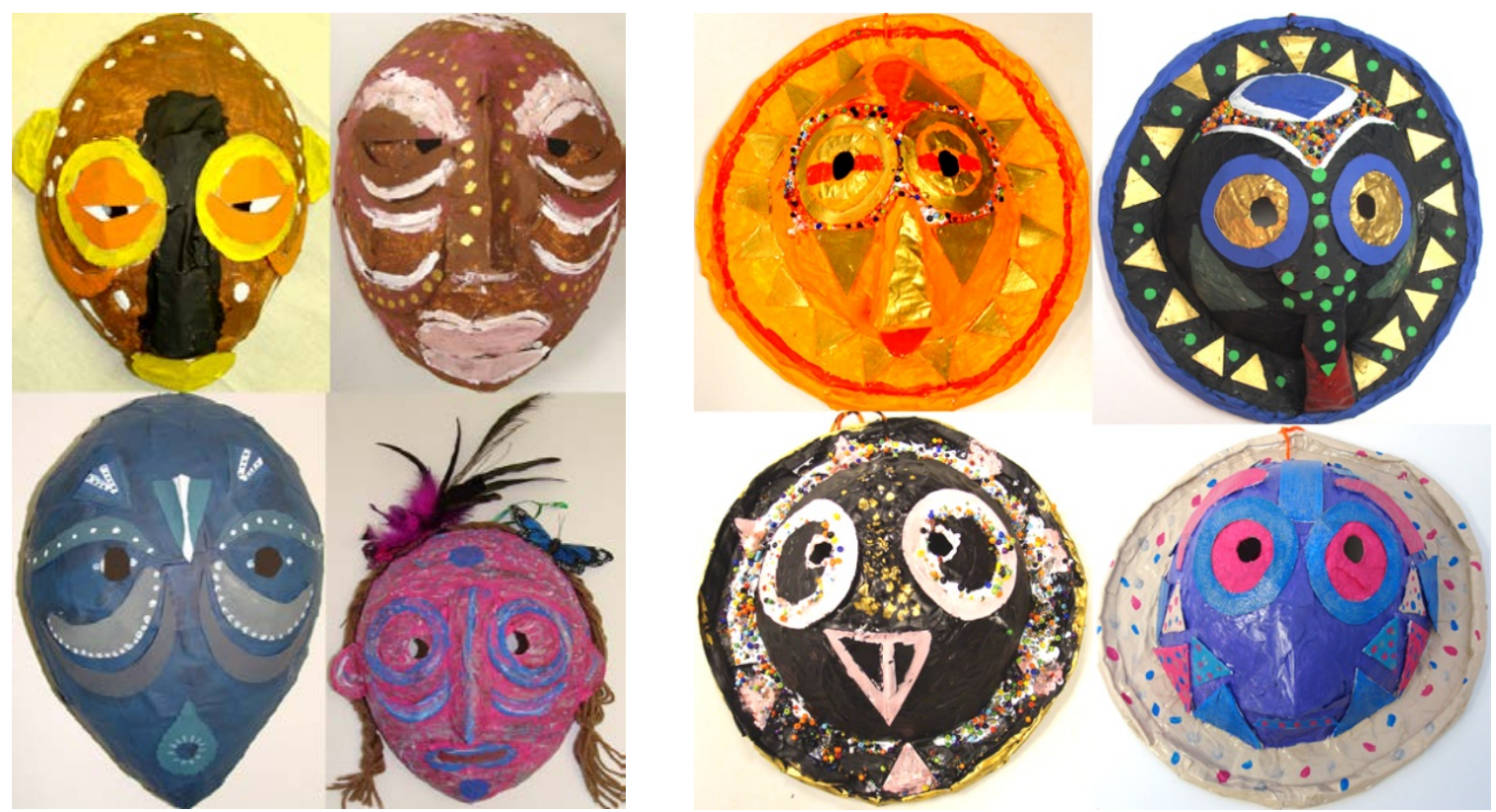

Figure 3. Chokwe-style masks (four at left) \& Luba-style masks (four at right)

\section{Participant Insights after Mask-Making}

Table 2 shows participant insights regarding the project. One participant of African heritage noted:

I appreciated someone acknowledging my culture. I knew about African masks and had seen pictures of them, but had never had the opportunity to make one until this workshop. It made me think about how African art is not privileged in the curriculum.

Participants without African heritage also valued the activity: "It is motivating to think about and try to capture the beauty of a person's life in the mask," and "I think African mask-making would be a fun, educational, and rewarding project to do with kids." These comments from both groups indicate a valuing of learning about African cultures leading to enhancement of cultural competence (LadsonBillings, 2005). The participants also discussed how the typical school curriculum might be reshaped to include similar mask-making activities with teachers as facilitators rather than direct instructors. 
Table 2

Insights from Making Masks

\begin{tabular}{|c|c|c|c|}
\hline Insight Category & $\begin{array}{l}\text { African } \\
\text { Heritage }\end{array}$ & $\begin{array}{l}\text { No African } \\
\text { Heritage }\end{array}$ & $\begin{array}{l}\text { Combined } \\
\text { Groups }\end{array}$ \\
\hline $\begin{array}{l}\text { Educational activity that took me out of my } \\
\text { comfort zone but gave me more confidence. }\end{array}$ & 3 & 1 & 4 \\
\hline $\begin{array}{l}\text { I enjoyed the mask making a lot. This would be } \\
\text { an important addition to the curriculum. }\end{array}$ & 3 & 1 & 4 \\
\hline $\begin{array}{l}\text { Mask-making allowed me to gain insights; the } \\
\text { longer I worked, the more insights I had. }\end{array}$ & 1 & 3 & 4 \\
\hline $\begin{array}{l}\text { I think it would be a fun, educational, and } \\
\text { rewarding project to do with kids. }\end{array}$ & 1 & 2 & 3 \\
\hline $\begin{array}{l}\text { Masks can capture the beauty of a person's life, } \\
\text { family, and ceremonial aspects. }\end{array}$ & 1 & 2 & 3 \\
\hline $\begin{array}{l}\text { This project combined problem solving with } \\
\text { religion, spirituality, the arts, history, and } \\
\text { affective realm. }\end{array}$ & 0 & 3 & 3 \\
\hline $\begin{array}{l}\text { Because of painting this mask, I like painting } \\
\text { and feel more love for art now. }\end{array}$ & 2 & 0 & 2 \\
\hline $\begin{array}{l}\text { I wish I had had more time to plan my mask and } \\
\text { consider all the symbolism. }\end{array}$ & 2 & 0 & 2 \\
\hline $\begin{array}{l}\text { I would love to create a mask that represented } \\
\text { my heritage. }\end{array}$ & 0 & 2 & 2 \\
\hline $\begin{array}{l}\text { I could see connections between all the African } \\
\text { masks. }\end{array}$ & 1 & 0 & 1 \\
\hline $\begin{array}{l}\text { It definitely makes me want to learn more about } \\
\text { African culture. }\end{array}$ & 1 & 0 & 1 \\
\hline
\end{tabular}

\section{Participants' Descriptions of their Mask-Making Process}

The adjectives and gerunds (i.e., - ing words) participants used to describe the mask-making work could be grouped into several categories by the constant comparative method. The two most frequently occurring descriptions referred to the creative work (imagining, innovating, birthing, and creating) and to actions used in mask-making such as painting, pinching, and working. Words referring to reflection and planning formed a third category of frequently mentioned words. Other categories of words frequently reported were words indicating transformation through artistic experiences, such as healing, growing, or transforming and words that were grouped into the category of mask inspirations (feeling, inspiring, and loving the culture).

Some differences emerged in participants' reflective responses about descriptive words they might use to describe their mask-making work. First, participants without African heritage expressed many words that indicated appreciation of the richness of African culture (accepting, amazed, thanking, 
listening, receptive, caring), while those with African heritage did not respond with words that fit within this category. Perhaps many participants without African heritage were not familiar with African masks; this experience supported their appreciation of African culture. Participants with African heritage may have identified with Africans, not feeling a need to express self-appreciation. Second, more participants without African heritage noted having a measure of "transformation through Art" in their responses to making masks, suggesting both their appreciation for this learning opportunity and recognizing personal growth through producing African art. They also noted more reflection and planning than the participants with African heritage. These reflective processes may be related to emerging intercultural competence in which the participants engaged in perspective-taking and processing of emotions related to the unfamiliar cultural experience. These participants without African heritage also evidenced some negative emotions such as "scary," "unknown," and "tricky." Some of these feelings may be related to the challenge of making an effective, well-proportioned and aesthetically-pleasing mask. Participants without African heritage remarked on their assessment of personal progress during mask-making (correcting, evaluating, assessing, scrutinizing). This finding may demonstrate a cultural response to the mask-making experience. In African American culture, emphasis is not placed on perfection; rather, value is placed on innovative approaches in which one uses ideas or materials uniquely (personal communication from several African American participants). This focus on self-definition rather than acceptance of others' standards or renderings of one's role may be related to the Black feminist movement that challenged White patriarchal definitions of femininity and racial stereotyping (Collins, 1986; hooks, 1999). The maskmaking process elicited culturally relevant responses that could potentially benefit educators who work with children with African heritage. Instead of viewing creative responses or alternative approaches from children with African heritage from a deficit perspective in a school context that often values one "correct" response, educators can demonstrate cultural competency in being open to a variety of methods of solving a problem. Children who come from homes in which creativity, uniqueness, and freedom are valued often have difficulty transitioning to a school environment in which there is one right answer and everyone is expected to do a task the same way. Integration of the arts with associated appreciation of creativity and original approaches may allow multiple cultural styles to be valued in the classroom. Research has shown that more creative ideas are generated when individualism, rather than collectivism, is valued (Goncalo \& Staw, 2006).

\section{New Intercultural Understandings}

Participant responses to "New Intercultural Understandings" suggested additional culturally relevant findings for both groups, as shown in Table 3. Those participants with African heritage noted respect for women as matriarchal figures in society with comments like "women hold a society together." In African-American households, women are visible family and community leaders. 
In many African societies, such as the Yoruba, mothers are revered for their role in the preservation of society (Makinde, 2004). Becoming more aware of cultural differences in household structures of African Americans and their relation to cultural heritage may assist teachers in interacting with African American families in a more culturally sensitive way.

Several participants recognized cultural universals of communication through symbols (line 2 of Table 3), the human need for love, and family structures such as marriage (line 4 of Table 3 ). These observations indicated growth in the emotional skills of understanding the origins of other people's feelings, a component of intercultural competence (Stier, 2006).

Table 3

New Intercultural Understandings Expressed by Participants

\begin{tabular}{|c|c|c|c|}
\hline New Intercultural Understanding & $\begin{array}{l}\text { African } \\
\text { Heritage }\end{array}$ & $\begin{array}{c}\text { No } \\
\text { African } \\
\text { Heritage }\end{array}$ & $\begin{array}{l}\text { Combined } \\
\text { Groups }\end{array}$ \\
\hline $\begin{array}{l}\text { Mask symbolism was unique for different groups, even those that } \\
\text { lived nearby }\end{array}$ & 3 & 4 & 7 \\
\hline We are all connected in some way; many symbols are universal. & 2 & 4 & 6 \\
\hline $\begin{array}{l}\text { Women hold a society together; valuing of women and their } \\
\text { fertility }\end{array}$ & 4 & 0 & 4 \\
\hline $\begin{array}{l}\text { Masks symbolize important life aspects: beauty, love, marriage; } \\
\text { items can be added to masks to show progression. }\end{array}$ & 3 & 1 & 4 \\
\hline $\begin{array}{l}\text { The significance of masks - how cultures project their identity } \\
\text { through them }\end{array}$ & 1 & 2 & 3 \\
\hline The importance of using arts to preserve cultural history & 0 & 2 & 2 \\
\hline $\begin{array}{l}\text { Communication with ancestors, family history, were important to } \\
\text { African peoples }\end{array}$ & 1 & 1 & 2 \\
\hline I better understand African cultures & 1 & 1 & 2 \\
\hline Africans were connected to the Earth & 1 & 0 & 1 \\
\hline
\end{tabular}

\section{Reflections of Cultural Identity}

Differences existed in the category of "Participants' Insights Related to Cultural Identity," as shown in Table 4. Participants without African heritage expressed a desire to delve into their own cultural heritage, sharing that making an African mask prompted them to question and become more curious about this. Adults working with students of diverse cultures need to first recognize and understand their own heritage and worldview before they are able to comprehend the cultural perspectives of students (McAllister \& Irvine, 2000). Moreover, some 
participants without African heritage began to make connections between African culture and their own heritage with a few noting increased empathy towards Africans. This increased caring for those of another culture supports intercultural understanding and world citizenship.

Table 4

Participants' Insights Related to Cultural Identity

\begin{tabular}{|c|c|c|c|}
\hline Insights Related to Cultural Identity & $\begin{array}{l}\text { African } \\
\text { Heritage }\end{array}$ & $\begin{array}{l}\text { No African } \\
\text { Heritage }\end{array}$ & $\begin{array}{l}\text { Combined } \\
\text { Groups }\end{array}$ \\
\hline $\begin{array}{l}\text { This activity caused me to question my own heritage, cultural } \\
\text { identity and become more curious }\end{array}$ & 0 & 8 & 8 \\
\hline I chose colors and symbols that relate to me personally & 5 & 2 & 7 \\
\hline Being proud of who I am & 3 & 1 & 4 \\
\hline $\begin{array}{l}\text { Enjoyed learning more of the history and meaning behind } \\
\text { African masks }\end{array}$ & 4 & 0 & 4 \\
\hline $\begin{array}{l}\text { I made connections between African culture and my own } \\
\text { cultural heritage. }\end{array}$ & 0 & 4 & 4 \\
\hline $\begin{array}{l}\text { Noticing the beauty of the different cultures and how it is } \\
\text { expressed in masks and the brown earth tone colors of } \\
\text { masks }\end{array}$ & 3 & 0 & 3 \\
\hline $\begin{array}{l}\text { We need to be more caring and sensitive to the more difficult } \\
\text { lives of some Africans and other people. }\end{array}$ & 0 & 2 & 2 \\
\hline
\end{tabular}

\section{Themes from Wording in Participant Poems}

Analysis of the words used throughout participants' double-cinquain poems, presented in Table 5, demonstrated a general similarity of word choice with participants using words that described themes such as power, love, spirit, adventure, beauty, and pain related to their mask. However, a sizable difference emerged in participant's use of words regarding "spirit," the most frequently used vocabulary category. Participants without African descent used more spiritualthemed words when writing about their masks. These participants may have focused on spiritual aspects of their mask's symbolism for various reasons. They may have recognized the spiritual meaning of the African masks and expressed it. Alternatively, they may have decided to personalize their masks with meaningful spiritual symbols of their own choosing because they did not identify with African symbolism. Perhaps with increasing opportunities to explore and participate in African artistic traditions, participants without African heritage may better understand and find points of identification with African cultures. Considering that many participants without African heritage expressed the desire to delve into their own cultural heritages, this workshop may have been a starting point in becoming more aware of the cultural differences and identities of self and others. This knowledge of both the "other" culture and one's own culture is part of intercultural content competency (Stier, 2006). Such sensitization will assist 
those who work with youth in becoming more effective, culturally competent leaders, as one must recognize one's own cultural identity before being able to appreciate the rich cultural identities of others.

Table 5

Vocabulary Categories Used in Double Cinquain Poetry

\begin{tabular}{|c|c|c|c|c|}
\hline Theme & Representative Words & $\begin{array}{l}\text { African } \\
\text { Heritage }\end{array}$ & $\begin{array}{l}\text { No African } \\
\text { Heritage }\end{array}$ & $\begin{array}{l}\text { Combined } \\
\text { Groups }\end{array}$ \\
\hline Spirit & $\begin{array}{l}\text { blessings, enlightening, healing, } \\
\text { philosophical, spiritual }\end{array}$ & 8 & 44 & 52 \\
\hline Love & $\begin{array}{l}\text { caring, compassion, harmony, heartfelt, } \\
\text { loving }\end{array}$ & 21 & 20 & 41 \\
\hline Power & $\begin{array}{l}\text { empowered, gender-equality, heroic, } \\
\text { leader, powerful }\end{array}$ & 16 & 19 & 35 \\
\hline Adventure & $\begin{array}{l}\text { adventuring, exciting, intriguing, } \\
\text { outstanding, uninhibited, wild }\end{array}$ & 20 & 12 & 32 \\
\hline People & adult, African, ancestors, family, people & 18 & 11 & 29 \\
\hline Pain & $\begin{array}{l}\text { fear, holocaust, lethal, pain, sorrow, } \\
\text { traumatic }\end{array}$ & 17 & 11 & 28 \\
\hline Beauty & $\begin{array}{l}\text { attractive, beautiful, elegant, graceful, } \\
\text { shining }\end{array}$ & 13 & 12 & 25 \\
\hline Joy & $\begin{array}{l}\text { celebrating, dancing, happy, joyful, } \\
\text { jumping }\end{array}$ & 8 & 13 & 21 \\
\hline Communication & $\begin{array}{l}\text { emotional commentary, explaining, } \\
\text { expressing, sharing, teaching }\end{array}$ & 4 & 9 & 13 \\
\hline Creativity & $\begin{array}{l}\text { birthing, creating, dreaming, } \\
\text { metamorphosis, transformation }\end{array}$ & 6 & 6 & 12 \\
\hline Nature & $\begin{array}{l}\text { animals, environment, garden, grazing, } \\
\text { natural }\end{array}$ & 4 & 8 & 12 \\
\hline
\end{tabular}

An example double-cinquain poem written by a participant without African heritage follows. Notice the words referring to the "spirit" category, such as "spiritual," and the words related to "joy" such as "joyful," "celebrating," and "dancing." Participants without African heritage tended to focus their poems on similarities in mood and values to which they could relate.

$$
\begin{gathered}
\text { Maasai; } \\
\text { Joyful, proud; }
\end{gathered}
$$

Celebrating, educating, dancing;

Respect the world around;

Nature.

Protection; 
Remarkable, startled;

Seeking, learning, hoping;

Passing on the truth;

Respect.

The second poem shown here, written by a person with African heritage, uses several terms related to "people" such as "Luba," Woman," and "Ancestors," showing the person's connection to the African people. It also contains words related to the "adventure" category of Table 5 such as "dramatizing," "intriguing," and "exciting," indicating a strong involvement with the content, especially indicated by the use of "familiar" and "alive."

Luba;

Mysterious, proud;

Dramatizing, intriguing, unwavering;

Empowering dignity, honoring beauty;

Woman.

Beauty;

Familiar, alive;

Exciting, comforting, puzzling;

Reverencing strength, pride, elegance;

Ancestors.

\section{Conclusion}

Because of changing demographics in school populations nationwide, arts-based experiences for students and teachers are needed to promote valuing diverse cultural contributions. In the current investigation, participants not only learned cultural content, such as mask use and symbolism, but began or continued to develop an appreciation for the ethnic heritage of African groups and themselves. We found that members of both groups reported insights, connections, and new understandings from the workshop, making it appropriate for professionals with and without African heritage. Arts experiences that support deeper understandings of culture, allowing participants to learn the background and reasoning behind conventions, may eventually result in greater intercultural acceptance. Rather than merely providing step-by-step directions in how to reproduce a given cultural artifact, teachers may delve into the origins of the work, consider how those using the original felt and provide evidence of what the work represents on various levels. Then, students may create their own interpretations of the work, as our mask participants did. Making a mask meaningful to the self allowed each participant to recognize the significance of 
the work for others. Perspective-taking and role-playing through this maskmaking workshop strengthened participants' intercultural competency (Stier, 2006).

Projects that emphasize heritage build self-esteem and pride, while contributing to positive relationships in the classroom as peers discuss and recognize strong points of their work. Teachers should take time for students to value, ask questions, form cultural understandings, and make connections between other cultures and one's own. Planning for such activities must be intentional, with room being made in the crowded curriculum for this important work. Professional development workshops such as the one described here are needed as part of a network of experiences to prepare teachers to be culturally competent.

\section{References}

Allport, G. (1979). The nature of prejudice (25th ed.). New York, NY: Basic Books.

Aluko, Y. A. (2015). Patriarchy and property rights among Yoruba women in Nigeria. Feminist Economics, (ahead-of-print), 1-26. DOI:10.1080/13545701.2015.1015591

Bassani, E. (2005). Arts of Africa: 7000 years of African art. Monaco: Grimaldi Forum.

Babatunde, E. D., \& Setiloane, K. (2014). Changing patterns of Yoruba parenting in Nigeria. In H. Selin, Parenting across cultures (pp. 241-252). New York, NY: Springer.

Boyd-Franklin, N. (2013). Black families in therapy: Understanding the African American experience ( $2^{\text {nd }}$ ed.). New York, NY: Guilford Publications.

Brooklyn Museum. (2007). Collections: Arts of Africa: Gelede mask. Retrieved from http://www.brooklynmuseum.org/opencollection/objects/3014/ Gelede_Mask

Brophy, J., \& Alleman, J. (2006). Children's thinking about cultural universals. Mahwah, NJ: Lawrence Erlbaum.

Bucheli M., R. J., Goldberg, M. R., \& Phillips, A. (1991). Symposium: Arts as education. Harvard Educational Review, 61(3), 25-26.

Casimir, K. A., Nwakego, O. S., \& Umezinwa, E. (2015). Masking traditions and their behavioral functions in accounting for stability and order: A critical exposition of select study of West, East and Central African masks. Open Journal of Political Science, 5(2), 115-127.

Colleyn, J., \& Farrell, L. (2001). Bamana: the art of existence in Mali. African Arts, 34(4), 16-94. 
Collins, P. H. (1986). Learning from the outsider within: The sociological significance of Black feminist thought. Social Problems, 33(6), S14-S32.

Collins, E., \& Chandler, S. (1993). Beyond arts as product: Using an artistic perspective to understand classroom life. Theory into Practice, 32(4), 199203.

Council of Chief State School Officers (2013). Interstate Teacher Assessment and Support Consortium (InTASC): Model core teaching standards and learning progressions for teachers 1.0. Washington, DC: Author.

Dye, J. F., Schatz, I. M., Rosenberg, B. A., \& Coleman, S. T. (2000). Constant comparison method: A kaleidoscope of data. The Qualitative Report, 4(12). Retrieved from http://www.nova.edu/ssss/QR/QR4-1/dye.html

Faini Saab, J., \& Stack, S. F. (2013). John Dewey and Reggio Emilia: Using the arts to build a learning community. Learning across the early childhood curriculum. Advances in Early Education and Day Care, 17, 115-133.

Finley, C. (1999). The art of African masks: Exploring cultural traditions. Minneapolis, MN: Lerner Publications Company.

Galbusera, A., \& Levinson, J. (2012). Defining art. Methode-Analytic Perspectives, 1(1), 80-86.

Graziano, K. J. (2011). Working with English language learners: Preservice teachers and photovoice. International Journal of Multicultural Education, 13(1). 1-19. Retrieved from http://ijme-journal.org/index.php/ijme/article/ view/354

Gay, G., Dingus, J. E., \& Jackson, C. W. (2003, July). The presence and performance of teachers of color in the profession. Unpublished report prepared for the National Collaborative on Diversity in the Teaching Force, Washington, D.C.

Gay, G. (2005). Politics of multicultural teacher education. Journal of Teaching Education, 56(10), 221-228.

Gay, G. (2010). Culturally responsive teaching: Theory, research, and practice (2nd ed.). New York, NY: Teachers College Press.

Gay, G. (2015). Teaching to and through cultural diversity. Curriculum Inquiry, 43(1), 48-70.

Goncalo, J. A., \& Staw, B. M. (2006). Individualism-collectivism and group creativity. Organizational Behavior and Human Decision Processes, 100(1), 96-109.

Graham, M. (2009). The power of art in multicultural education: The international stories project. Multicultural Perspectives, 11(3), 155-161.

Gudykunst, W., \& Kim, Y. (2003) Communicating with strangers: An approach to intercultural communication (4th ed.) New York, NY: McGraw-Hill. 
Gullatt, D. E. (2008). Enhancing student learning through arts integration: Implications for the profession. The High School Journal, 91(4), 12-25.

Hahner, I., Kecskesi, M., \& Vajda, L. (2007). African masks: The Barbier-Mueller collection. New York, NY: Prestel.

Hamill Gallery of Tribal Art. (2010). Bembe masks. Retrieved from http://www.hamillgallery.com/BEMBE/BembeMasks/BembeMasks.html

Herskovits, M. J. (2004). The human factor in changing Africa. Oxon, UK: Routledge.

Hommel, W. (2011). The University of Central Oklahoma. Interactive Tour of the African Exhibit, Second Floor of the Chambers Library. Yoruba Gelede mask. Retrieved from http://library.uco.edu/archives/artworks/ African2ndfloor/AfricanSecondFloorlnteractive75.html

hooks, B. (1999). Ain't I a woman: Black women in feminism. Cambridge, MA: South End Press.

Howard, G. R. (2007). As diversity grows, so must we. Educational Leadership, 64(6), 16-22.

Jackson, III, B. W. (2012). Black identity development. In C. L. Wijeyesinghe \& B. W. Jackson, III. New perspectives on racial identity development: Integrating emerging frameworks ( ${ }^{\text {nd }}$ ed., pp. 33-50), New York, NY: New York University Press.

Jamison, D. J. (1999). Masks without meaning: Notes on the processes of production, consumption, and exchange in the context of first world-third world tourism. Journal of Macromarketing, 19(1), 8-19.

Johnson, L. (2002). Art-centered approach to diversity education in teaching and learning. Multicultural Education, 9(4), 18-21.

Jordán, M., De Smet, P. A. M., Peek, P. M., Quizon, C. A., Roberts, A. F., der Welt, H. D. K., \& Ambras, S. (2000). Revisiting Pwo (genre). African Arts, 33(4), 16-25+92-93.

Keim, C. (2009). Mistaking Africa: Curiosities and inventions of the American mind $\left(2^{\text {nd }}\right.$ ed.). Philadelphia, PA: Westview Press.

Ladson-Billings, G. (1995). But that's just good teaching! The case of culturally relevant pedagogy. Theory into Practice, 34(3), 159-165.

Ladson-Billings, G. (2005). Is the team all right? Diversity and teacher education. Journal of Teaching Education, 56(10), 229-234.

Makinde, T. (2004). Motherhood as a source of empowerment in Yoruba culture. Nordic Journal of African Studies, 13(2), 164-174.

Marmer, E., Marmer, D., Hitomi, L., \& Sow, P. (2011). Racism and the image of Africa in German schools and textbooks. The International Journal of Diversity in Organisations, Communities \& Nations, 10, 1-12. 
McAllister, G., \& Irvine, J. J. (2000). Cross cultural competency and multicultural teacher education. Review of Educational Research, 70(1), 3-24.

Montgomery, S. E., \& Rule, A. C. (2011). Integrating the arts: Pre-service elementary teachers make African masks of six cultures for social studies lessons with primary grade students. Social Studies Research and Practice, 6(1), 89-109.

Montgomery, Z. K., Ugoretz, S. B., Montgomery, S. E., Vander Zanden, S., Jorgensen, A. \& Rudic, M. (2014). Reconsidering the American dream and U.S. Latino culture in a college Spanish service-learning course. Journal of Community Engagement and Higher Education, 6(1), 3-16.

National Center for Education Statistics. (2014). The condition of education. Washington, DC: Author. Retrieved from http://nces.ed.gov/programs/coe/ indicator_clb.asp

Olajubu, O. (2003). Women in the Yoruba religious sphere. Albany, NY: State University of New York Press.

Ola Orie, O. (2011). The structure and function of Yoruba facial scarification. Anthropological Linguistics, 53(1), 15-33.

Oreck, B. (2004). The artistic and professional development of teachers: A study of teachers' attitudes toward and use of the arts in teaching. Journal of Teacher Education, 55(1), 55-69.

Purnell, L. (2002). The Purnell model for cultural competence. Journal of Transcultural Nursing, 13(3), 193-196.

Purnell, L., \& Pontious, S. (2014). Cultural competence. In R. A. R. Gurung (Editor), Multicultural approaches to health and wellness in America [volume 1 of 2 volumes] (pp. 1-28). Santa Barbara, CA: Praeger.

Rule, A. C., \& Montgomery, S. E. (2011). Reflections of pre-service elementary teachers after learning about an African culture through mask-making. Social Studies Research and Practice, 6(1), 58-74.

Rule, A., Montgomery, S., Tallakson, D., Stichter, M., Barness, A., \& Decker, A. (2012). Teacher candidate attitude changes after experiencing an artsintegrated unit on Africa. Social Studies Research and Practice, 7(2), 1531.

Sleeter, C. (2001). Preparing teachers for culturally diverse schools: Research and the overwhelming presence of whiteness. Journal of Teacher Education, 52(2), 94-101.

Stier, J. (2006). Internationalisation, intercultural communication and intercultural competence. Journal of Intercultural Communication, 11(1), 1-12.

Vecsey, C. (1983). Facing death, masking death, in Luba myth and art. Journal of Religion in Africa, 14(1), 24-45.

Waddington, S. (2012). Keeping African masks real. School Arts, 112(3), 17-22. 
Zenkov, K., Pellegrino, A., Harmon, J., Ewaida, M., Bell, A., Lynch, M., \& Sell, C. (2013). Picturing culturally relevant literacy practices: Using photography to see how literacy pedagogies matter to urban youth. International Journal of Multicultural Education, 15(2), 1-20. Retrieved from http://ijmejournal.org/index.php/ijme/article/view/555/891

Zwirn, S., \& Graham, M. (2005). Crossing borders: The arts engage academics and inspire children. Childhood Education, 81(5), 267-273.

\section{Author Contact}

Audrey C. Rule: audrey.rule@uni.edu University of Northern lowa, 1227 West 27th Street, Cedar Falls, IA 50614, USA

Sarah E. Montgomery: sarah.montgomery@uni.edu University of Northern lowa, 1227 West 27th Street, Cedar Falls, IA 50614, USA

Gloria Kirkland Holmes: gloria.holmes@uni.edu University of Northern lowa, 1227 West 27th Street, Cedar Falls, IA 50614, USA

Dwight C. Watson: dwight.watson@uni.edu University of Northern lowa, 1227 West 27th Street, Cedar Falls, IA 50614, USA Yvonne Ayesiga: ayesigay@uni.edu University of Northern lowa, 1227 West 27th Street, Cedar Falls, IA 50614, USA 